\title{
FINK A HEIDEGGER PŘI ČETBĚ PARMENIDA
}

\author{
IVAN BLECHA, Katedra filozofie, Filozofická fakulta Univerzity Palackého v Olomouci, Olomouc, ČR
}

BLECHA, I.: Fink and Heidegger on Reading Parmenides

FILOZOFIA, 74, 2019, No 6, pp. $427-439$

Eugen Fink and Martin Heidegger met in 1966 to read Heraclitus. The differences between their conceptions led to significant differences in their commentaries. Fink considered the term of "fire" as the fundamental term in Heraclitus' philosophy because it reminded him of his concept of "the world", while Heidegger focused on the concept of logos and saw in Heraclitus' work an attempt to connect the concealed and the unconcealed aspects of Being, which are accessible to man. Similar differences in their views can be found also in their reading of Parmenides. Fink evaluates Parmenides in a more or less standard way and rebukes him for defining Being as a counterpart to absolute non-Being. Thus, he considers him as one of the thinkers who have brought confusion rather than clarity to the tradition of the question of Being. On the other hand, Heidegger puts Parmenides (due to the specific translation of the terms noein and einai) in the tradition of Anaximander and Heraclitus, that means among those thinkers who rightly understand the relationship of thinking and Being as an attunement to the openness of the world. In the course of these analyses Heidegger himself begins to abandon the strict duality of "beings and Being" as well as the concept of "ontological difference" and is inclined towards the original phenomenological understanding of the links between the concealed and the unconcealed, between the manifest and the hidden.

Keywords: Heidegger - Fink - Parmenides - Ontology - Being - being - Lichtung - Phenomenology - World

V roce 1966 se Eugen Fink a Martin Heidegger potkali na slavném semináři k Hérakleitovi (Heidegger - Fink 1970). Seminář vedl Fink a bylo zřejmé, že Hérakleita interpretuje v duchu svého pojetí světa. Heidegger kriticky přizvukoval a tu a tam projevil jistou míru nespokojenosti, protože samozřejmě četl Hérakleita zase svýma očima. Fink pojímal roli světového ohně (a blesku) jako předjímání pojmu světa: dění v otevřeném poli, jež podle Finka uděluje jednotlivým jsoucnům prostor, čas a vzájemné vymezení. Uchopit celek světa našimi poznávacími schopnostmi ovšem není podle Finka možné, lze o něm jen spekulovat nebo jej zakoušet prostřednictvím hry. V jeho dimenzi končí fenomenologie. Heidegger naopak fenomenologicky zdůrazňuje, že Hérakleitos umí myslet zjevná jsoucna jako něco, co v sobě skrývá nezjevné a nechá svět vyvstávat v uspořádání, které 
může být za určitých podmínek člověku srozumitelné. Což Heidegger shrnul do vlastního rozlišení, když Finkovi jednou nadhodil: „Vaše cesta hérakleitovských interpretací vede od ohně k $\log u$, moje cesta vede od $\log u$ k ohni“ (Heidegger, Fink 1970, $179-180$ ).

Tyto neshody se ukazují i při úvahách nad myšlením jiného předsokratovského filosofa, Parmenida. Rád bych se na ně nyní podíval podrobněji. Finkovy a Heideggerovy náhledy je ovšem $\mathrm{v}$ tomto prípadě možné porovnávat jen na dálku.

\section{Parmenidův objev a Fink}

Předsokratovské období v sobě podle Finka obsahuje mnohem větší zlom, než je ten, který v řeckém myšlení představují Platón a Aristotelés. Leží mezi myšlením světa iónských filosofů a myšlením bytí eleatů - což reprezentují dvě velké figury: Hérakleitos a Parmenidés. Právě Parmenidés založil ontologickou filosofii, a ta tvoří nepřetržitou linii až $\mathrm{k}$ dnešku. Přišel totiž s něčím, čeho si tehdy všiml jen málokdo: se zjištěním, že „jsoucí jest“" (Fink 1957, 46).

Toto na první pohled banální konstatování musíme ovšem pochopit v jeho vážných důsledcích. Jestliže všechno jsoucí prostě a zásadně je, pak je jenom toto jsoucí a nemůže existovat nic. K bytí nemůže patřit žádná nicota, musí být vždy, všude a vcelku, po všechny časy. Taková ontologie, která opírá bytí o zásadní rozdíl vůči nic, přičemž ale toto nic není schopna myšlenkově uchopit, natož definovat, je podle Finka vlastně nihilismem. Nihilismus proto není nějaký duchovní proud, který najednou vtrhl do evropských dějin na sklonku křestanství s počátkem osvícenství, ateismu atd., ale je př́tomen už v raných obdobích evropského myšlení, tam, kde chce filosofie ochránit bytí před ničím, ale přitom touto snahou právě bytí na toto nic váže jako na jeho temný stín. „Kdekoliv je okruh bytí jsoucího poměřován mírou, která je určena ideou bytí, jež ze sebe vyloučilo nic, můžeme už o nihilismu mluvit“ (Fink 1957, 51).

Z Parmenidova objevu plynou další konsekvence a komplikace. Bytí se musí myslet - a myšlení proto není nic jiného než v posledku myšlení bytí. Myšlení je říkání-jest, je prritakávání bytí, předpokládá, že to, nač myslí, jest (Fink 1957, 55). Ale my smrtelníci si bytostnou povahu takového myšlení neuvědomujeme. Žijeme ve zmatcích, nejasnostech, v nedorozuměních. Není-li možné, aby mohlo něco ne-být, jak si totiž máme vysvětlit naši každodenní zkušenost se zánikem, smrtí, konečností? Proto hned říkáme, že něco jest, a hned zase, že něco není, a myslíme tím často i radikální negaci. Smrtelníci neumějí prostě onu jednoduchost bytí plně uchopit, neumějí podržet negativitou nedotčené bytí. Mají-li se lidé nějak přivést ke správnému náhledu, musí jim pomoci bohyně. Ta názorně a přesvědčivě zdůvodňuje, jak zmatečné je myslet tak, že mícháme bytí a nebytí, a že jedinou skutečně uchopitelnou cestou je cesta ,jest“; to je myšlenka myšlenek, myšlení ve své podstatě. Velikost eleatské filosofie je v odvaze 
vyslovit něco, co je ve zřejmém rozporu s tím, co obvykle přijímáme jako běžné (Fink 1957, 50).

Tohle je v dějinách filosofického myšlení obecně známé, v Parmenidovi je však podle Finka ještě něco, co by se dalo nově interpretovat. Bohyně v Parmenidově básni totiž nabízí tři cesty: cestu zapletenou do klamů, které člověku brání vůbec daný stav věcí pochopit. Pak cestu, která by snad nějak byla už pokusem o reflexi situace, byla by míněním, jenže míněním, které si pořád pohrává s možností, že něco „není“ nebo „nemusí být“. To je cesta doxa. A pak je tu třetí, pravá cesta, která díky bohyni dovolí dojít k jasnému zjištění, že jsoucí jest a nemůže nebýt nic a že tudíž jako důsledek platí, že myslet a být je totéž. Ve filosofické tradici se soudí, že Parmenidés cestu doxa úplně zavrhuje. Fink ale ukazuje, že cesta skrze doxa by se nemusela zcela odmítat a že bychom ji dokonce mohli dobře využít $\mathrm{k}$ tomu, abychom nebyli ohroženi nihilismem jako sám Parmenidés.

Parmenidés totiž podle Finka nikde výslovně nenabádá, že by se člověk měl doxa úplně zbavit. Ve světě mínění se vždy musíme nějak naskýtat, ostatně bohyně nabízí k pravému myšlení „,cestu“, nikoli skok, a cesta přece vyžaduje čas, prostor i pohyb, tedy světské, pozemské náležitosti. Vědění je navíc závislé na jazyce, myslíme skrze sémata a ta nemohou být mimo náš svět. Lidské přemýšlení o bytí nemůže překročit základní situaci, v níž je člověk jako konečná bytost zakotven: nemůže být náhle přesazen do neochvějného srdce obkružující pravdy (Fink 1957, 78).

Výlučnost myslitele poučeného bohyní pak nespočívá v ničem jiném než ve vědění o omezenosti člověka. Myslitel neopouští své vězení, ví o něm však. Smysly a každodenním životem musí zůstat ve světě mínění, pouze myšlením může tento svět překročit - ve spekulativních výkonech (Fink 1957, 79). Když si tento základní vztah ujasníme, porozumíme lépe vnitřní jednotě všech částí parmenidovské básně. Bez poučeného vědění jsme spoutáni pozemským míněním, aniž si to uvědomujeme. Neuvědomujeme si ovšem ani to, že jsme vězni. To je špatně. Poučeni o stavu věcí se paradoxně teprve stáváme vězni skutečnými, ale to proto, že se myšlením můžeme mimo své vězení povznést (Fink 1957, 80). A to je podle Finka docela slušné východisko pro rozumné úvahy o povaze světa.

Doxa je podle Parmenida vázána na prostor, čas a pohyb: jevící se věci jsou prostorové, časové, pohybující se. Nebo jinak: prostor, čas a pohyb jsou udomácněny v jevení, zdání. Je třeba Parmenidovi přiznat jako velkou zásluhu, že na takto jevy obrátil cílenou pozornost a že určil, že jevení vỉbec je základní charakteristikou pro prostor, čas a pohyb (Fink 1957, 95). Každé jsoucno, smyslová danost, se musí nějak naskýtat v prostoru a v čase a být nějak hybné. Je však podle Finka velkou Parmenidovou chybou, že toto niterné přebývání (In-sein) konečných jsoucen v prostoru, v čase a v pohybu zbytečně devalvoval právě oním předpokladem, že bytí, které jsoucnům jejich 
výskyt umožňuje, nemůže z principu nebýt, takže musí mít zcela opačné atributy než právě tato jsoucna. Jejich úkolem nadále bylo nepřekážet čistému myšlení v cestě za plnou pravdou bytí, protože jejich povaha byla pro vymezení povahy celku reality bezcenná.

Jak tedy pochopit skrze sémata onen rozdíl mezi jednotlivými jsoucny a celkem bytí, který jim umožňuje jejich výskyt, jejich jevení, abychom se vyhnuli Parmenidově pasti? Musí tu jít jen o striktní protiklady? Eon je např́klad myšlen jako akineton, jako nehybné. Musí to být ale nehybnost ve smyslu radikálního opaku k pohyblivému, ptá se Fink? Parmenidés byl oslněn myšlenkou, že bytí z principu nemůže nebýt, takže jako podklad všeho pohyblivého jevení musí být nehybné a plně stojící jen v sobě samém. Zapomněl však na jiný možný vztah: co když protiklad hybného není v nehybném, ale v hýbajícím, protiklad časového nikoli v bezčasí, ale v časování, prostorově vymezeného nikoli v neprostorovosti, ale $\mathrm{v}$ tom, co prostor uděluje? $\mathrm{K}$ tomu je třeba myslet jinak, ne tak, jako se myslí o konečných věcech, u nichž se umí předpokládat odlišný stav jen jako jejich úplný opak, tedy paradoxně pořád v jejich dimenzi (Fink 1957, 101). Nebot' jestliže má být jedinou alternativou k času bez-časí, pak právě myslíme skrze sugesci časem. Že se snažíme myslet opak, neznamená, že jsme se od povahy časového jsoucna dostatečně odpoutali - někdy může být opak něčeho na tom, čemu je protikladný, více závislý, než bychom byli ochotni připustit.

Je tedy vážná otázka, zda nemáme hledat nějakou vlastní dimenzi pro prostor, čas a pohyb; ne tam, kde Parmenidés předpokládal ne-prostorovost, bez-časí a ne-hybnost, ale ve směru nějakého jiného myšlení o Eon (Fink 1957, 102). Tradiční filosofie se tohoto úkolu zhostit nedovedla a zamotávala se spíše do paradoxů nitrosvětského myšlení, což dokládá i Zenón a jeho aporie (Fink 1957, 103).

Fink proto Parmenidovu představu upravuje. Jestliže se bytí ve sfěre jevů nějak projevuje, uplatňuje, a to fakticky; nemůže od ní být zcela odděleno, nemůže být ani jejím radikálním opakem. A sféra jevi̊ proto nemůže být čirým zdáním. Dejme tomu, že Eon je neprostorový, ale to přece může znamenat, že prostě není tak prostorový, jak jsou konkrétně prostorové konečné věci, není zde na rozdíl od nějakého tam, není omezen skrze hranice, které by ho oddělovaly od ostatních jsoucen. Podobně je to s časem a pohybem (Fink 1957, 107).

Nedal by se tedy onen předpokládaný celek bytí, jenž má být za prostorově a časově určenými pohybujícími se jevy něčím ne-prostorovým, ne-časovým, ne-hybným, myslet spíše jako jejich před-prostorová, před-časová či před-hybná podmínka? A nemáme $\mathrm{k}$ tomu při troše pozornosti a cviku dispozice v našem vědomí a myšlení, na něm postaveném? Například každé znovuvyvolání př́tomnosti něčeho minulého předpokládá přece také připomenutí jeho bývalé tělesnosti, prostorové orientace: i ve své představě vidím dům nějak natočený, v nějaké perspektivě. Fink tvrdí, že takto výkony 
svého vědomí umíme postihnout samu podmínku tělesnosti, samu prostorovost prostírajícího se jsoucna, aniž bychom potřebovali vázat jeho konkrétní původní výskyt na skutečné zde a nyní, myslíme je přesto v něčem, co tento výskyt dřive umožňovalo a co tak stojí v jeho základu. Takový úkon vědomí pak vlastně proniká k něčemu základnějšímu, než jsou jevová konkréta, totiž k samotnému procesu jejich konstituce (srv. Fink 1988, 48 - 49). Vědomí tu vlastně provádí jakousi imaginaci, což připomíná hru. Fink si vskutku ve své filosofické koncepci pojmem hry vypomáhá: v ní přece děláme z konkrétních, hmatatelných jsoucen, daných v reálném čase a prostoru, něco, co má jakýsi fiktivní čas a prostor, tedy něco, co se nevyčerpává vymezitelnými parametry, ale přece jako by jejich původní určení mělo. Chlapci si v dětském pokoji hrají na rytíre, ale zápasy mezi nimi nebo s draky se dějí v dimenzi, kterou nevymezují čtyři stěny. Tato dimenze má však přece svou orientaci, své horizonty a své předtím a potom: skrze hru jaksi zakoušíme, co to znamená udělovat prostor a čas (Fink 1993).

Tato obemykající pradimenze by pak byla tím, co by ve vztahu k jevícím se jednotlivinám nebylo právě ničím protikladným, ale spíše zakládajícím, umožňujícím, předpokládaným. Pak by byl sice mezi jevy a touto dimenzí, tedy bytím, rozdíl, nikoli však protiklad, takže by nemělo smysl o bytí mluvit jako o něčem ne-hybném, ne-časovém či ne-prostorovém a radovat se z toho, že prostě jenom plně ,jest“.

Fink tento zakládající celek ovšem nenazývá bytím, ale světem. Podle Finka je proto nutné myslet jednotlivá jsoucna ve vazbě na tento svět, musí být uchopena jako obsažená v jeho celku a svět potom jako to, co je obemyká. Obsaženost nebo obemykání zde však samožrejmě nesmějí být chápány v běžném smyslu, jako když třeba míníme, že menší věc spočívá ve větší (Fink 1957, 99). Mezi jevy a světem, který jim umožňuje jevení, není protiklad, není to ani stupňování nebo rozlišení, které by bylo dáno abstrakcí. Přesto je mezi nimi zásadní rozdíl, nebot' mezi jevem a jevením takový rozdíl předpokládat musíme. Je ovšem něčím, co se obtížně myslí a co je třeba trvale předpokládat jako tzv. „kosmologickou diferenci“. Finkovi se zdálo, že právě obraz ohně u Hérakleita by mohl být jedním z rozumných způsobů, jak si roli světa jako dárce jevů přiblížit.

Jak to všechno Parmenidés myslel ve své básni, zůstane asi nejasné. Umožnil však tradici, aby byl pochopen jednostranně, a představuje tak v evropském myšlení osudové scestí: bytí může být myšleno bez svého jeviště, bez světa (Fink 1957, 156 - 157). S Parmenidem začíná ve filosofii ,zapomenutost na svět“ (Fink 1957, 96), totiž na jeden z možných pojmů, jímž by se dal vysvětlit ,původ“ a ,základ“ toho, co se zde a nyní ukazuje a dává ve své jsoucnosti. Podle Finka je to větší prohřešek než ,zapomenutost na bytí“". 


\section{Heidegger, Parmenidés a problém bytí}

Také Heidegger hledá v Parmenidovi potvrzení svého pojetí světa a toho, co ho zajímá celý život, totiž problému bytí. Jeho četba předsokratiků je jiná než Finkova, a proto i v Parmenidovi vidí něco jiného. Předběžně řečeno: nikoli užitečnou roli doxa, která nás vede $\mathrm{k}$ pokoře před omezeností lidské existence a $\mathrm{k}$ předpokladu světa jako dárce jevových dimenzí prostoru a času, ale poukaz na to, že bytí je třeba vytušit $\mathrm{v}$ jeho zdrženlivém schraňování se v odkrytosti (srv. Heidegger 1992, 211), čemuž jsme jako lidé specifickým způsobem prítomni.

Heidegger se proto také při četbě Parmenida zaměřil na intepretaci jiných zlomků než Fink. Finka zajímala př̌devším analýza tř́ cest, Heidegger pracuje s nejznámějším Parmenidovým zlomkem, ovšem ve svérázném překladu, který samožrejmě odpovídá Heideggerovým pozicím.

Víme, že nejznámější Parmenidův zlomek (zl. B 2 a 3 z Prokla, Klementa aj.) zní řecky: To gar auto noein estin te kai einai. V obvyklém překladu: „Vždyt’ myslit a býti je totéž“" (Svoboda 1962, 67). ${ }^{1}$

$\mathrm{K}$ tomu, abychom pochopili, jak tento zlomek čte Heidegger, musíme nejprve podat stručný výklad Heideggerovy filosofické koncepce.

V době, kdy se pro něj stal Parmenidés obzvlášt' zajímavý, byl Heidegger přitahován ještě dvěma dalšími předsokratiky: Anaximandrem a Hérakleitem. $Z$ jejich filosofie si pro sebe vzal především dva klíčové pojmy: fysis a logos (Parmenidés pak bude mít zásluhu o rozvedení třetího pojmu - alétheia). Heideggerovi znamená řecké slovo fysis „,vyrašení - např́klad vyrašení růže - ve smyslu vycházet najevo, předvést se, vydávat se“ (Heidegger 1996a, 79). Takto mluvil o povaze celé reality Anaximandros a Heidegger se tedy nerozpakuje předpokládat, že pod pojmem fysis vlastně staří Řekové mysleli př́mo „bytí“ (Heidegger 1996a, 79). Zároveň jim ale onen procesuální charakter fysis, dynamika vzcházení, vnukal představu (patrnou také u Anaximandra), že nutnou součástí celého procesu je chvilkové spočinutí ve tvarech, které vzcházející bytí nabývá: tedy v tom, „co tu nepohnutě setrvává“" ve viditelných mezích a co bychom podle Heideggera mohli považovat za ,jsoucí (Heidegger 1996a, 79). Víme ovšem také od Anaximandra, že toto nepohnuté setrvávání je pro celkovou povahu fysis neúplným stavem, z hlediska její dynamiky nepatřičným. Vše, co na chvilku zůstane $\mathrm{v}$ takových mezích, co nabude peras, je podle řádu času zase postrkováno pryč, aby dalšímu momentu vzcházení splatilo „pokutu a trest“. Tento řád vzcházení a zacházení, který se týká jednotlivých vzešlostí (jsoucen) a který pro nás činí fysis zakusitelnou a srozumitelnou, je logos. To už je zase obzor myšlení Hérakleita, který si všímá toho, že fysis, ono vzcházení bytí do jevícího se jsoucna, se ve své zjevnosti

\footnotetext{
${ }^{1}$ Německy se ve vydání Dielse zlomek překládá: „Denn das Seiende denken und sein ist dasselbe“ (Diels 1903, 121).
} 
nevyčerpává, že se v ní tedy jaksi skrývá a působí v ní z odstupu. Důsledkem toho je zjištění, že „nezjevná harmonie je lepší než zjevná“ (zl. B 54 z Hippolyta; Svoboda 1962, 54). Tak je vše propojeno ve vzájemném dění protikladných stavů, jimž dominuje odkrývání a skrývání, nabízení a zadržování a které vytvářejí skvostnou harmonii, kterou Řekové označovali jako kosmos.

Z uvedeného lze podle Heideggera dovodit dále cosi, co pak najde vděčné uplatnění právě u Parmenida.

V Bytí a času považoval Heidegger pro filosofické uvažování za základní rozdíl mezi bytím a jsoucnem, tzv. ontologickou diferenci. Nyní se mu základní diference za pomoci předsokratiků proměnila na rozdíl mezi „stáním v odkrytosti“ a obemykajícím pozadím, jehož povahu chápe Heidegger jako „otevřenost“. Otevřenost, otevřené pole odkrývání je jakousi „oporou“ každému jevení: „V základu neskrytosti vládne otevřenost“ (Heidegger 1992b, 208). Bytí bytuje jako volná dimenze, v níž realizuje jsoucí svůj vstup do neskrytosti a skrze niž se také zachycuje v přítomnu vůči nám (Heidegger 1992b, 240). „Všude, kde něco přítomného přichází vstříc, nebo jen prodlévá vůči jinému přítomnému [...] všude tam již vládne otevřenost, je ve hře volné pole“ (Heidegger 2006, 23). Otevřeno, do něhož je každé jsoucno uvolněno, „toto otevřeno je bytí samo. Každé odkryté je jako takové ošetřováno v otevřenu bytí..."(Heidegger 1992, 224) A tady je důležité si uvědomit: jednotlivá jsoucna se jeví, stojí v odkrytosti, ale bytí, tedy otevřenost sama, jež jim to umožňuje, se plně do žádné takové odkrytosti nedostává. Přesněji podle Heideggera: „Bytí se tím, že se odkrývá do jsoucna, odtahuje a skrývác (Heidegger 2012a, 29). Dalo by se pak říci, že bytí se skrývá v odkrývání jsoucen, dělá to, čemu Heidegger říká ,zdrženlivé schraňováni'“ (Heidegger 1992a, 211).

Už Řekové to tak mnohdy chápali, jenže když zkusmo o takovém otevřeném poli mluvili, redukovali jeho působnost na světlo a světlené efekty (Heidegger 1992b, 214). Není divu, že hlavní slovo nakonec získala Platónova strategie, která pro „zření“ idejí potřebuje světlo: a to v nejvyšším možném stupni záření. I Heidegger ono otevřené pole, „které zaručuje možné jevení a ukazování se“, (Heidegger 2006, 23) nazývá Lichtung (česky snad světlina). Světlina je tím, „, čem čistý prostor a ekstatický čas a vše, co je v nich př́itomné i nepřítomné, má teprve místo, na němž se vše shromažd’uje, a které je pro všechno místem chráněným“ (Heidegger 2006, 25). Heidegger ale hned upozorňuje, že není nutné tento pojem spojovat (jenom) s představou světla: a když, tak ve správném rozsahu. Německé substantivum Lichtung odkazuje totiž ke slovesu lichten (vylehčit). Adjektivum licht je př́buzné slovu leicht (lehký). Lichtung je tedy něco, co prolehčuje (a následně nechává osvětlit) to, co před tím mohlo být zarostlé, zakryté: jako mýtina v lese. Na mýtinu (světlinu) pak samozřejmě dopadá více světla, takže je „světlá“, ale její původ je v prosekání, pročištění lesa. Světlinu nikdy netvoří až světlo, nýbrž světlo světlinu předpokládá. A světlina, ono 
otevřené pole, je volné nejen pro jas a temno, nýbrž i pro zvuk a jeho ztišení, pro znění a odeznění. ${ }^{2}$

Zatím by Heideggerovy úvahy tohoto typu korespondovaly s Finkovou prèstavou světa. Jak je tomu však u Heideggera s pozicí člověka v této strukturere? Co z toho je nám př́istupně dáno a co v modu, který zřejmě nebude uchopitelný smyslově? Už u Anaximandra jsme viděli, že jsoucí se pro nás ustavuje jako to, co z pole otevřena vstoupí do specifické časové př́tomnosti: postavení-proti-nám, a to navíc do mezí, jež je dovolují uchopit. Přitom ale je nutné předpokládat, že ono pole „otevřena“ nikam nemizí, že tu také nějak je, i když jinak než v modu momentální prítomnosti.

Němčina poskytuje Heideggerovi při popisu této situace jistou výhodu: rozlišuje totiž dvojí př́tomnost - Anwesenheit a Gegenwart. Anwesenheit je „bytí při tom“, asi tak, jako když mluvíme o tom, že jsme byli prítomni nějaké události, nějakému představení, proslovu atp. (Heidegger 2007, 14). Otevřené pole je třeba chápat právě takto: že je „při-tom“, když něco vzchází, i když se samo drží zpět. I my jsme při něm, opíráme se nějak o ně, ale nestojí proti nám, nemá konkrétní podobu. Gegenwart je naopak něco jako „zdržování se vůči něčemu“, co už je z původního „,bytípři-tom“ vykrojeno jako jeho část, a to především v časovém smyslu. Gegenwart je něco, co jsme z oné širší Anwesenheit uchopili, postavili proti sobě, ustanovili, podrželi (proto ten časový rozměr), co jsme z ní prožili, co jsme zakusili (třeba i konkrétním smyslovým vjemem) atp. Žádná Gegenwart nemůže být bez otevřeného pole Anwesenheit, naopak to ale neplatí (Heidegger 2007, 15). Heidegger se pak pokouší myslet bytí tak, abychom pochopili, že to není nic, co by šlo odvodit z parametrů stání v časové př́tomnosti či bez-prostřednosti, z Gegenwart, ale co musíme umět uchopit jako otevřenost „bytí-při-tom“, jež má zcela jiná určení. Zatímco např́íklad vǔči Gegenwart můžeme mluvit o ne-prítomnosti nějakého jsoucna, Anwesenheit nemá žádný takový protipól - nemá kde „nebýt“.

Právě z jakési neschopnosti držet rozdíl zmíněných dvou ,přítomnosti'“ se zrodila platónská tradice, přetrvala $\mathrm{i} v$ aristotelismu, ve scholastice a $\mathrm{v}$ teorii moderní subjektivity, vědy a techniky atp. Díky nazírající povaze myšlení, které u Platóna převládlo, se za základ bytí začala považovat idea (eidos) - ideální vzezření, odvozené od způsobů, jak se ukazuje konkrétní jsoucno. Poznání je pak bráno jako zření idejí a vlastně především jako „záchrana“ jsoucna před sestupem do zakrytosti. Idea je plná odkrytost. V platónské koncepci se bytí (idea) zploštuje do plného zjevu.

Je nyní ovšem lépe vidět, proč se po tomto výkladu Heidegger pokouší doložit, že máme-li plně porozumět všemu, co Parmenidés často tak nezřetelně nabízí, je nutné lépe přeložit dva kličové termíny z uvedeného slavného zlomku - totiž noein a einai.

\footnotetext{
${ }^{2}$ Krátkou úvahu o tom, jak nejlépe překládat Heideggerův pojem světliny, nabízí M. Pokorný $(2018,151)$.
} 
Obvyklý překlad slovesa noein pomocí „myslet“ je podle Heideggera problematický. Noein má totiž v archaické řečtině spíše význam „po-střehováni““, „zaznamenání", ba animálně i jakéhosi „„ětření “ ${ }^{3} \mathrm{~V}$ němčině tomu podle Heideggera nejspíše odpovídá sloveso vernehmen (zaslechnout, dozvědět se, spatřit, postřehnout, všimnout si). A v němčině také existuje ke slovesu vernehmen podstatné jméno Vernunft. Proto je vlastně s vědomím původního významu toto slovo trefnějším překladem řeckého nús než slova duch nebo myšlení, která se používají. Je-li nús Vernunft, pak původně právě ne jako čisté abstraktní myšlení a rozjímání, ale jako zavětření, postřehnutí, jež ješš nemá konkrétní podobu, ale jež je otevřeno a naladěno na fakt, že tu něco jest.

Je to podobné jako u divoké zvěře, když něco zavětří. Větření je první nastavení se celku, otevřenu: laň zvedne hlavu, a aniž by přesně věděla, co chce slyšet, vidět nebo cítit, otevře se čiré prítomnosti toho, co kolem jest: chce být „přitom“. Větření není smyslové poznávání, ale otevřenost pro něco s předpokladem, že se nastavíme na evidenci něčeho, co jest (byt' neurčitě). Je to podmínka a výchozí stav každého dalšího upressnění situace. $\mathrm{V}$ otevřeném poli větření může pak něco konkrétního vyvstat, a to může být signál $\mathrm{k}$ útěku, př́padně u predátorů signál $\mathrm{k}$ útoku. „Aby bylo možné myslet bytí [...] je zapotřebí procitnutí v blízkosti nenápadného jsoucna, kteréžto procitnutí náhle spatří, že jsoucí ,jest““ (Heidegger 1992b, 222). Procitnutí u tohoto ,jest“ a posléze získaná trvalá bdělost pro ně, jakož i „,bdělost pro světlinu jsoucího - to tvoří podstatu bytostného myšlení" (Heidegger 1992b, 222).

„Zavětřením“, postřehujícím uchopením, stvrzujeme svou sounáležitost s př́tomností otevřeného pole jevení, světliny, bytí, a dáváme najevo svou dispozici sdílet s bytím tentýž prostor, vynacházet se v něm, být-při-něm a tak mu jistým způsobem už rozumět, „,vědět“, co to znamená „být". Naššestí mělo podle Heideggera řecké slovo einai původně právě tento význam a je nutné je překládat jako Anwesen (Heidegger 1986, 397), jako vždy prítomné pole otevřena. ${ }^{4}$ A toto otevřené pole není „půda“, na kterou bychom měli sestoupit, nic „nenese“, ale ani „nezdůvodňuje“ jako základ, prríčina. Půdou, základnou, příčinou může být jen jedno jsoucno vůči jinému, nikdy ne bytí samo (Heidegger 1992b, 223). Na bytí samo se žádná kauzální úvaha nemůže vztahovat.

Takže myslet věc samu znamená být „zasazen do volného pole světliny“ (Heidegger 2006, 27). A Heidegger soudí, že připomínku světliny můžeme při troše dobré vưle najít i u Parmenida: v jeho básni jsme přece nabádáni, že se máme nastavit tak, abychom byli schopni „zakusit nechvějící se srdce neskrytosti“ (Heidegger 2006, 29). Tím se podle Heideggera míní právě světlina otevřeného pole. „Klidné srdce světliny

\footnotetext{
${ }^{3}$ Stejnou etymologii uvádí i Wolfgang Schadewaldt $(1978,71,163)$.

${ }^{4}$ I Wolfgang Schadewaldt je mínění, že einai má původně tento význam (srv. Schadewaldt 1978, $193-194)$.
} 
je místo ticha, z něhož se teprve dává něco takového jako sounáležitost bytí a myšlení, tj. prítomnění a postřehování“ (Heidegger 2006, 31).

Ukazuje se, že bytí vlastně myšlení potřebuje. „Člověk vhlíží, zacházeje se jsoucím, předem do otevřena tím, že stojí $\mathrm{v}$ otevírajícím a otevřeném rozvrhu bytí. Bez tohoto otevřena, skrze něž bytí samo bytuje, by nemohlo být jsoucno ani odkryto ani zakryto“ (Heidegger 1992b, 237). A z druhé strany: věc musí mít možnost vstoupit do pole nastraženého otevření, očekávání, aby se na ní dalo předpokládat rozčlenění na momentálního státní v současnosti (jako věc) a na otevřené př́ítomnění samotné. „Bytí potřebuje člověka, aby bytovalo, a člověk náleží bytí, protože tak může realizovat své nejzazší určení jako Da-sein“ (Heidegger 1989, 251). Př́tomnění (Anwesenheit) předpokládá stálé, člověka angažující, jeho dostihující, jím dosažené prodlévání (Heidegger 2007, 17).

Teprve o takto chápaném noein ř́ká Parmenidés ve slavném verši, že je totéž jako být. Přitom ale nemůže výraz „totéź“ (to auto) v Parmenidově verši znamenat, že by noein a einai byly identické, nýbrž pouze to, že k sobě neoddělitelně patří. Jde o prolnutí horizontu jevení s horizontem otevření, nastražení. „Otevřeno je ono nejbližší, co v základu neskrytosti vždy spolumíníme, aniž bychom to ovšem vědomě registrovali, co však zároveň nemůžeme plně promýšlet, neřkuli vůbec nějak předem zahlédnout $\mathrm{v}$ jeho vlastní podstatě. Takže $\mathrm{z}$ této zakládající otevřenosti samotné se může odehrávat každé zakoušení jsoucího a být jí řízeno“" (Heidegger 1992b, 212). Jenom tehdy, když nás $v$ Parmenidově výroku oslovuje tento nárok bytí a nikoli něco prèdmětného z mnohosti jsoucen, může být porozumění jeho „větě“ správné (Heidegger 1992b, 5).

Takže Heideggerův německý překlad Parmenidova zlomku zní: „Sein west als Anwesenheit in der Gegenwart des Vernehmens“ (Heidegger 2012b, 179). Český překlad zlomku podle Marie Pětové by zněl: „Bytí bytuje jako prrítomno ve vstř́icnosti rozuměni““ (Pětová 2012, 140).

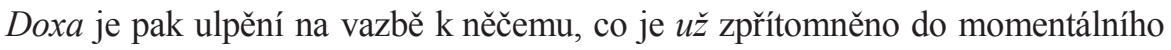
stání naproti. Doxa neumí registrovat pole otevřena a doložit, že je podmínkou jejího fungování (Heidegger 2000, 246). Drží se toho, co se už rozvinulo a co se smrtelníkům bezprostředně nabízí a co je poutá: totiž prítomnícího se bez schopnosti brát ohled na prítomnění samo. To, co se takto jednostranně nabízí, považuje doxa za pravdu, alétheia: je to ale ulpění pouze na něčem odkrytém. Nebere-li se však ohled na celek přítomnění, tedy i na to skryté, nejde o celou pravdu (Heidegger 2000, 246). Do oboru neskrytosti (Unverborgenheit) náleži právě tak odkrývání (Entbergung) jako skrytost (Verborgenheit) (Pětová 2012, 149). Jen ti poučení, dbalí hlasu bohyně-pravdy, přijdou na to, jak je to možné a nenechají se zmást. ${ }^{5}$

\footnotetext{
${ }^{5} \mathrm{Na}$ základě takových výkladů musel dokonce i sám Heidegger revidovat své dřívější pojetí pravdy (srv. Heidegger 2006, 33 a násl.).
} 


\section{Finkovo a Heideggerovo hodnocení Parmenida}

Fink tvrdí, že svět je dárcem prostoru a času a zdá se na první pohled, jako by koneckonců odpovídal Heideggerově představě otevřeného pole, světliny. V tomto vymezení vskutku příliš rozdíl nebude. Podstatné je něco jiného, totiž onen ,poznávací“ aspekt. Podle Finka Parmenidés jako ,rámec“ pro vzcházení jednotlivých jevů předpokládá „,bytí“, které umí vymezit jen v ostré negaci k „,nemyslitelné“ nicotě. Tím zpětně devalvuje jevy na pouhé klamy, protože to pravé, co je údajně za nimi, je právě absolutní jedno, nehybné, nevznikající a nezanikající. Fink tento obemykající rámec nezavrhuje, nazývá ho „světem“, snaží se ho však zbavit smrtící dichotomie, do níž ho Parmenidés a jeho dědicové vložili. Svět skýtá pohyb, ale nemusí být nutně „,nehybný“, umožňuje různorodost jsoucího, ale nemusí být nutně ,jeden“ jako jejich ostrý protiklad. Myslet správně parametry světa ovšem znamená spolehnout se na zcela specifické imaginativní schopnosti našeho spekulativního myšlení a na dovednost hry. Hra je symbolem světa, bude Fink tvrdit (Fink 1993). Co je však důležité: svět, tedy procedura jevení (Fink ji říká Vorschein), nepotřebuje člověka. Nabízí se mu jen v jevech jako nahlédnutelné konkrétum (Fink tomu ř́ká Anschein), v momentálním vzezření. Proto je svět člověku bytostně nedostupný, pochopitelný jen symbolickou analogií hry.

U Heideggera je tomu jinak. U Heideggera je svět chápán jako „pole otevřena“, jako takový je podmínkou porozumění všemu dalšímu jevení a skrývání a člověk je mu jako „světlině byti'“ nastaven, prolíná se s ním. I zdánlivě exkluzivní cesta bohyně Pravdy nás nechává vstřícně nastavené bytí - ba toto naše nastavení potřebuje. Nejde přitom jako u Finka o symbolický svět hry, ale o součást naší existence, ba dokonce o součást závažného úkolu - přispívat k dění samotného bytí.

Fink hodnotí Parmenida víceméně standardně: kárá ho za vymezení bytí ve stylu nihilismu. Řadí ho tedy mezi myslitele, kteří tradici otázky po bytí spíše zamlžili, než aby jí prospěli. Heidegger naopak řadí Parmenida (ovšem díky zvláštnímu překladu klíčového zlomku) do linie k Anaximandrovi a Hérakleitovi, tedy mezi ty myslitele, kteří rozevřeli to správné tázání se po bytí. ${ }^{6}$ Do potíží dostal filosofii až Platón.

Heideggerovo přesvědčení o př́buznosti těchto myslitelů a o prolínání jejich filosofie ovšem ruší tradovaný ostrý rozdíl mezi Hérakleitem a Parmenidem. Parmenidés vskutku není podle Heideggera obyčejný protipól k Hérakleitovi, tedy „,zastavovatel“ dění, jak bývá v komentářích a posléze v učebnicích uváděn, ale ten, kdo podobně jako Hérakleitos správně pochopil, jakým zpo̊sobem se může člověk dobrat „pravdy bytí“، „Hérakleitos, kterému je připisována nauka o dění v ostrém protikladu k Parmenidovi, ř́ká ve skutečnosti totéž co on“" (Heidegger 1983, 105).

\footnotetext{
${ }^{6}$ Ona řada jmen se dá také vyjádřit řadou odpovídajících pojmů: fysis - logos - aletheia.
} 
Pro vlastní vývoj Heideggerova myšlení je tu ale ve hře ještě jeden zajímavý a možná i velmi důležitý aspekt: ačkoli je Heidegger nucen mluvit u Parmenida o „bytî“, ukázali mu další předsokratikové, že se tento pojem vlastně stává zbytečným. Sám Heidegger je nyní nucen chápat bytí jako otevřenost, přítomnění, světlinu, zdrženlivé sebe-schraňování. Ptá se sám sebe: „Nezní pak název úkolu myšlení místo ,bytí a čas': světlina a př́romnění?“ (Heidegger 2006, 39) Tím ovšem nutně musí v Heideggerově koncepci ztratit na významu i původní pojem ,jsoucího“ a spolu s ním i „ontologická diference“.7 Jako zcela základní se tu do hry zase dostávají bytostně fenomenologické pojmy. Zatímco Fink skrze Parmenida fenomenologii opouští, Heidegger se naopak do lůna, z něhož kdysi vyšel a jemuž se poněkud odcizil (k zármutku Edmunda Husserla), začal zase pokorně vracet.

\section{Literatúra}

DIELS, H. (1903): Die Fragmente der Vorsokratiker. Berlin: Weidmannsche Buchhandlung.

FINK, E. (1957): Zur ontologischen Frühgeschichte von Raum - Zeit - Bewegung. Den Haag: Martinus Nijhoff.

HEIDEGGER, M. (1983): Einführung in die Metaphysik. GA Bd. 40. Frankfurt am Main: Vittorio Klostermann.

HEIDEGGER, M. (1986): Seminare. GA Bd. 15. Frankfurt am Main: Vittorio Klostermann.

HEIDEGGER, M. (1989): Beiträge zur Philosophie (Vom Ereignis). GA Bd. 65. Frankfurt am Main: Vittorio Klostermann.

HEIDEGGER, M. (1992a): Grundfragen der Philosophie. GA Bd. 45. Frankfurt am Main: Vittorio Klostermann.

HEIDEGGER, M. (1992b): Parmenides. GA Bd. 54. Frankfurt am Main: Vittorio Klostermann.

HEIDEGGER, M. (1996a): Evropa a německá filosofie. Přel. J. Šindelář, I. Šnebergová. Filosofický časopis, 44 (1), $45-52$.

HEIDEGGER, M. (1996b): Bytí a čas. Přel. I. Chvatík, P. Kouba, M. Petříček jr., J. Němec. Praha: Oikúmené.

HEIDEGGER, M. (2000): Vorträge und Aufsätze. GA Bd. 7. Frankfurt am Main: Vittorio Klostermann.

HEIDEGGER, M. (2006): Konec filosofie a úkol myšlení. Přel. I. Chvatík. Praha: Oikúmené.

HEIDEGGER, M. (2007): Zur Sache des Denkens. GA Bd. 14. Frankfurt am Main: Vittorio Klostermann.

HEIDEGGER, M. (2012a): Anaximandrưv výrok. Přel. I. Chvatík. Praha: Oikúmené.

HEIDEGGER, M. (2012b): Der Anfang der abendländischen Philosophie (Anaximander und Parmenidés). GA Bd. 35. Frankfurt am Main: Vittorio Klostermann.

HEIDEGGER, M., FINK, E. (1970): Heraklit. Seminar Wintersemester 1966/1967. Frankfurt am Main: Vittorio Klostermann.

${ }^{7}$ O potížích s pojmy „byti““ a ,jsoucno“, zdůrazněných právě úvahami nad Parmenidem, viz Leško (2017, 357 a násl.). 
FINK, E. (1988): IV. Cartesianische Meditation. Teil 1. Husserliana-Dokumente. Bd. II/1. Dordrecht - Boston - London: Kluwer Academic Publishers.

FINK, E. (1993): Hra jako symbol světa. Přel. M. Petříček. Praha: Český spisovatel.

LEŠKO, V. (2017): Heidegger a Parmenidés. Filozofia, 77 (5), 357 - 370.

PĚTOVÁ, M. (2012): Myšlení počátku a konce metafyziky. Praha: TOGGA.

POKORNÝ, M. (2018): K sémantice Lichtung u Heideggera. Reflexe 55 (2018). Praha: Oikúmené.

SVOBODA, K. (1962): Zlomky předsokratovských myslitelů. Přel. K. Svoboda. Praha: Nakladatelství Československé akademie věd.

SCHADEWALDT, W. (1978): Dia Anfänge der Philosophie bei den Griechen. Frankfurt am Main: Suhrkamp.

STEINMANN, M. (2007): Die Humanität des Seins. Das Denken des späten Heidegger und sein Verhältnis zu Parmenidés. In: M. Steinmann (ed.): Heidegger und die Griechen. Frankfurt am Main: Vittorio Klostermann.

Stat' vznikla v rámci projektu, řešeného na Filosofické fakultě Univerzity Palackého v Olomouci pod názvem Reflexe současných aktualizaci vybraných směrů kontinentálni filozofie

(IGA_FF_2019_008).

Ivan Blecha

Katedra filosofie

Filosofická fakulta Univerzity Palackého v Olomouci

Křížkovského 12

77180 Olomouc

Česká republika

e-mail: ivan.blecha@upol.cz 